\title{
A Review of Studies Dealing with Tree Rings and Rockfall Activity: The Role of Dendrogeomorphology in Natural Hazard Research
}

\author{
M. STOFFEL \\ Groupe de Recherches en Géomorphologie (GReG), Department of Geosciences, \\ Geography, University of Fribourg, chemin du Musée 4, 1700 Fribourg, Switzerland \\ (E-mail: markus.stoffel@unifr.ch)
}

(Received: 25 February 2005; accepted: 7 September 2005)

\begin{abstract}
Over the last few years, rockfall research has increasingly focused on hazard assessment and risk analysis. Input data on past rockfall activity were gathered from historical archives and lichenometric studies or were obtained through frequency-volume statistics. However, historical records are generally scarce, and lichenometry may only yield data with relatively low resolutions. On forested slopes, in contrast, tree-ring analyses may help, generally providing annual data on past rockfall activity over long periods. It is the purpose of the present literature review to survey the current state of investigations dealing with tree-ring sequences and rockfall activity, with emphasis on the extent to which dendrogeomorphology may contribute to rockfall research. Firstly, a brief introduction describes how dendrogeomorphological methods can contribute to natural hazard research. Secondly, an account is provided of the output of dendrogeomorphological studies investigating frequencies, volumes or spatial distributions of past rockfall activity. The current and potential strengths of dendrogeomorphology are then presented before, finally, the weaknesses of tree rings as natural archives of past rockfall activity are discussed and promising directions for further studies outlined.
\end{abstract}

Key words: rockfall, tree rings, dendrogeomorphology, frequency, volume, spatial patterns, seasonality

\section{Introduction}

In mountainous regions, rockfalls repeatedly impinge on inhabited areas or transportation corridors (Kienholz et al., 1988; Hungr et al., 1999; Budetta, 2004), where they occasionally destroy buildings (Evans and Hungr, 1993) or even cause fatalities (Bunce et al., 1997; Guzzetti, 2000; Baillifard et al., 2003). As a result, rockfalls have become one of the most intensively studied geomorphic processes of the cliff zone. Initially, studies mainly relied on direct observations in the field (Luckman, 1976; Douglas, 1980; Gardner, 1983) or lichenometric analysis (Bull et al., 1994; Luckman and 
Fiske, 1995; André, 1997; McCarroll et al., 2001) to derive frequencies, volumes or spatial aspects of past rockfall activity.

More recently, research has gradually evolved in the direction of hazard assessment and risk analysis (e.g., Hungr and Beckie, 1998; Guzzetti et al., 2004). Data on past rockfall activity is commonly gathered from historical archives (e.g., Hantz et al., 2003; Barnikel, 2004, Guzzetti and Tonelli, 2004) and further investigated with frequency-volume statistics (DussaugePeisser et al., 2002; Dussauge et al., 2003) or frequency densities (Malamud et al., 2004).

However, Guzzetti et al. (1999) pertinently emphasize that historical records are only rarely available and difficult to obtain for single events or event-prone areas. Lichenometry also has its limitations, as the method (i) tends to be hindered by a paucity of widely accepted measurement and analytical procedures (Bull and Brandon, 1998) and (ii) may only yield relatively low resolution data. Finally, observation-based rockfall studies consider present rates of activity and rarely extend for more than a few years, thus making it difficult to scale-up results either spatially or temporally (McCarroll et al., 1998). As a consequence, information on frequencies (how often), volumes (how large), spatial distributions (where) or the seasonality (when) of past rockfall activity remains scarce and, for the most part, fragmentary.

Tree rings, in contrast, have the potential to yield yearly resolved data on frequencies, volumes, spatial distributions and/or the seasonal timing of past events (DeGraff and Agard, 1984; Guzzetti et al., 1999). Consequently, tree rings have been widely used, over the last decades, in the analysis of landslides (e.g., Lateltin et al., 1997; Fantucci and Sorriso-Valvo, 1999; Stefanini, 2004), debris flows (e.g., Strunk, 1995; Baumann and Kaiser, 1999; Stoffel et al., 2005a), flooding (e.g., Hupp, 1988; LePage and Bégin, 1996; St. George and Nielson, 2003), snow avalanches (e.g., Patten and Knight, 1994; Rayback, 1998; Hebertson and Jenkins, 2003), earthquakes (e.g., Jacoby et al., 1988; Jacoby, 1997; Lin and Lin, 1998) and volcanic eruptions (e.g., Kaiser and Kaiser-Bernhard; 1987; Baillie, 1994; Biondi et al., 2003).

In contrast, tree rings have only rarely been taken into account when investigating rockfall on forested slopes, even though Schweingruber (1996: 272) persuasively argued that "geomorphological processes in mountain forests are very common and only dendrochronology is able to provide information about the frequency and extent of the past events". It is therefore the aim of this literature survey to give an overview of the results of studies dealing with tree rings and rockfall, with a description of, firstly, the different methods and approaches used in the field of dendrogeomorphology. Secondly, to illustrate the potential of dendrogeomorphology, examples are given of how frequencies, volumes, the spatial distribution or 
the seasonality of rockfall have been studied using dendrogeomorphological techniques. Finally, the strengths and weaknesses of tree rings as natural archives of past rockfall activity are discussed and promising directions for further studies outlined.

\section{Dendrogeomorphological applications and methods}

Over the past few decades, tree-ring research has gradually evolved from the dating of wood (dendrochronology, dendroarcheology) to the much broader field of dendroecology, including all areas of science involved in drawing environmental information from tree-ring sequences (Schweingruber, 1996). In this sense, 'dendrogeomorphology' represents one of the many subfields of dendroecology and has been widely used to study and date past geomorphic processes. The approach, developed by Alestalo (1971) and refined by Shroder (1978), takes advantage of the fact that trees form yearly increment rings that can precisely date external disturbances (see Figure 1).

Growth cycles in trees are driven by the seasonality of climate. In the temperate climate of the Northern Hemisphere, the 'vegetation period', and thus also cell growth, lasts from around May to September and can be divided into two distinct periods (Camarero et al., 1998; Rigling et al., 2002): At the beginning of the growth cycle, large thin-walled earlywood cells and (depending on the species) vessels are formed. Later on, reproductive cambium cells start producing smaller and denser latewood cells. Thereafter, cell growth ceases and 'dormancy' sets in (October-April). The subdivision of a tree ring into 'dormancy', earlywood and latewood is illustrated in Section 3.4. As trees react immediately to any type of disturbance, the position of abnormal growth features affecting a tree ring, such as scars, callus tissue, traumatic rows of resin ducts or reaction wood, can be used as dating indicators for the intra-seasonal timing of events with almost monthly resolutions (Brown and Swetnam, 1994; Ortloff et al., 1995).

Figure 2 summarizes different reactions of trees to geomorphic events and shows how growth responses may appear in tree-ring sequences. A tree's reaction to the impacts caused by snow avalanche, landslide, debris flow or rockfall can lead to (a) cell formation concentrating in areas vital for survival after decapitation and the loss of main branches; (b) scars that become overgrown after injury and (c) a gradual straightening of the stems through the formation of reaction wood after tilting due to instability or unilateral pressure. Sudden reductions in tree-ring growth may also occur as a reaction to the exposure of roots through erosional processes or the partial burying of the stem and subsequent reduction in nutrient supply (Strunk, 1997). In addition, the elimination of trees through geomorphic 


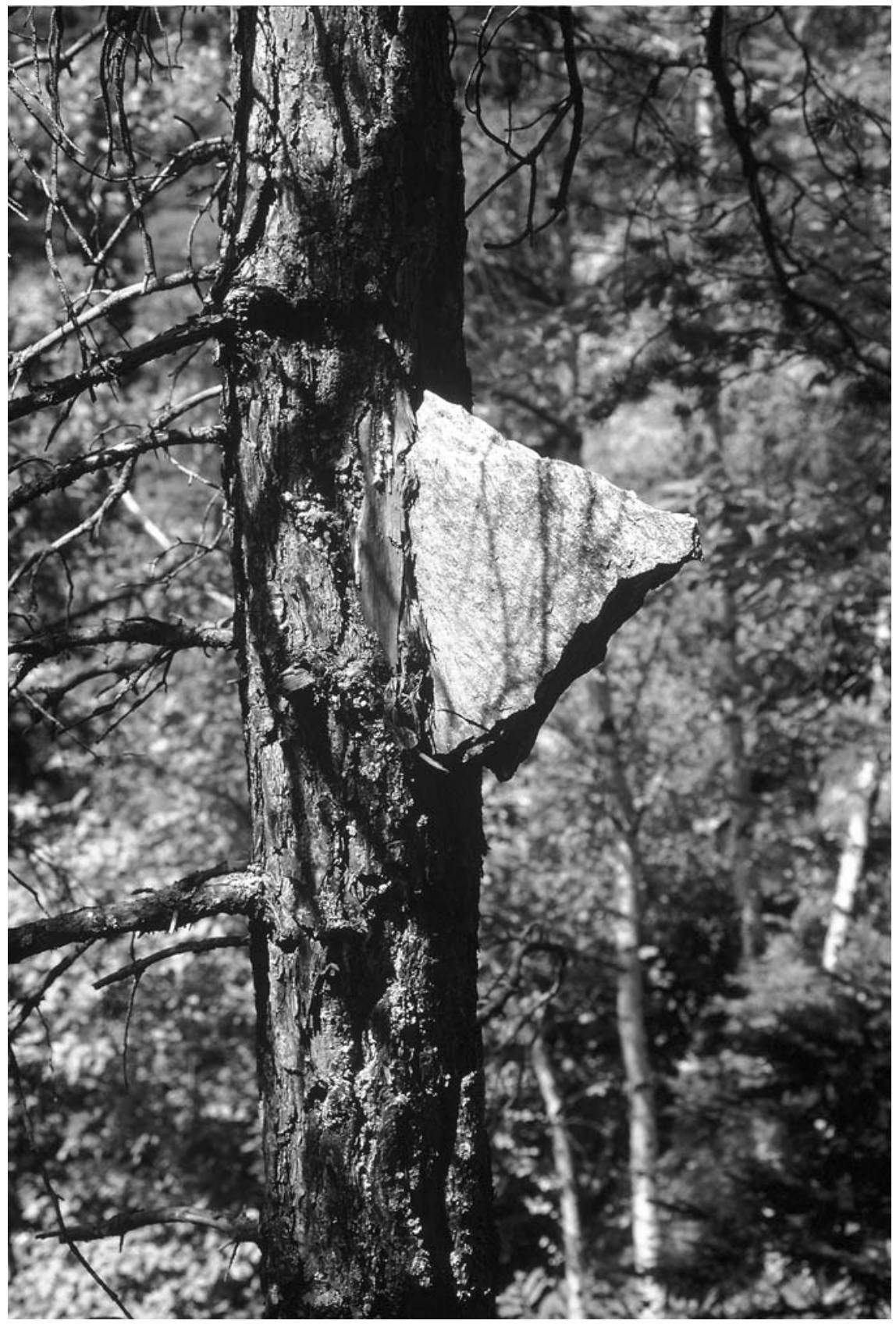

Figure 1. Trees are able to provide efficient protection from rockfall by slowing down or stopping falling, bouncing or rolling rocks and boulders. In the present case, a rock has even been lodged in a stem in the Ticino Alps, Switzerland. (Photo courtesy by Fritz $\mathrm{H}$. Schweingruber, used with permission). 


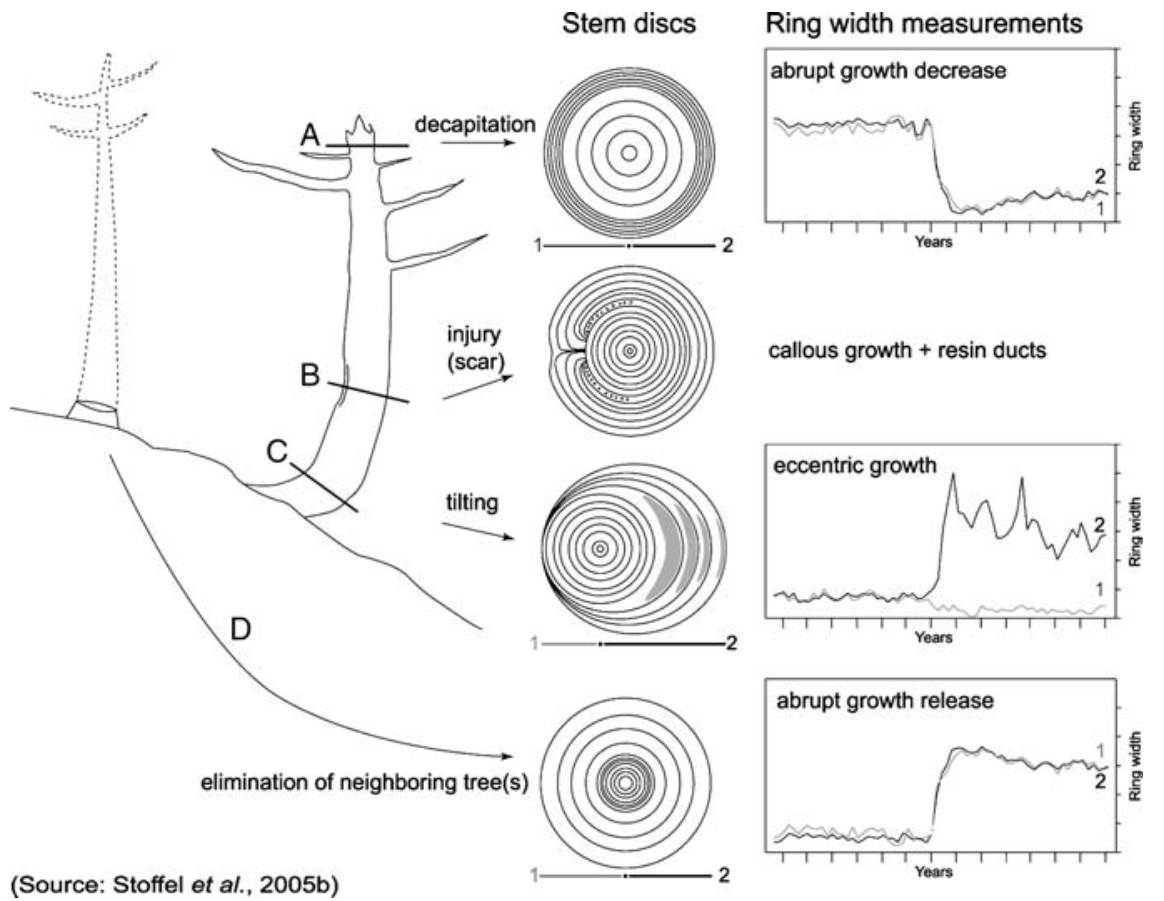

Figure 2. Evidence used to infer rockfall events from tree-ring sequences: Visual analysis of disturbed samples (left) as well as the measurement of tree-ring widths (right) enable identification of (a) sudden growth suppressions, (b) callus tissue and traumatic rows of resin ducts, (c) reaction wood or (d) growth releases.

events can result in (d) growth releases in undamaged neighboring trees as they take advantage of improved environmental conditions (e.g., more light, nutrients and water). Finally, after cambial damage certain conifer species may form traumatic rows of resin ducts. Further details on the principles of dendrogeomorphology or tree reactions to external processes can be found in Shroder (1980), Shroder and Butler (1987), Bräuning (1995) or Wiles et al. (1996).

Dendrogeomorphological analyses comprise both investigations in the field and work in the laboratory: In the field, detailed geomorphic investigations and process analyses must precede tree sampling. Only when the geomorphic process and its area of influence has been determined, should cores either be extracted from trees with increment borers or, ideally, stem discs (cross-sections) sawn. As illustrated in Figure 3, increment cores are normally taken in the fall line of the process in question, i.e. one core upslope (core c) and one core downslope (core d). In addition, and because rockfall may also injure trees laterally, further samples should be taken 


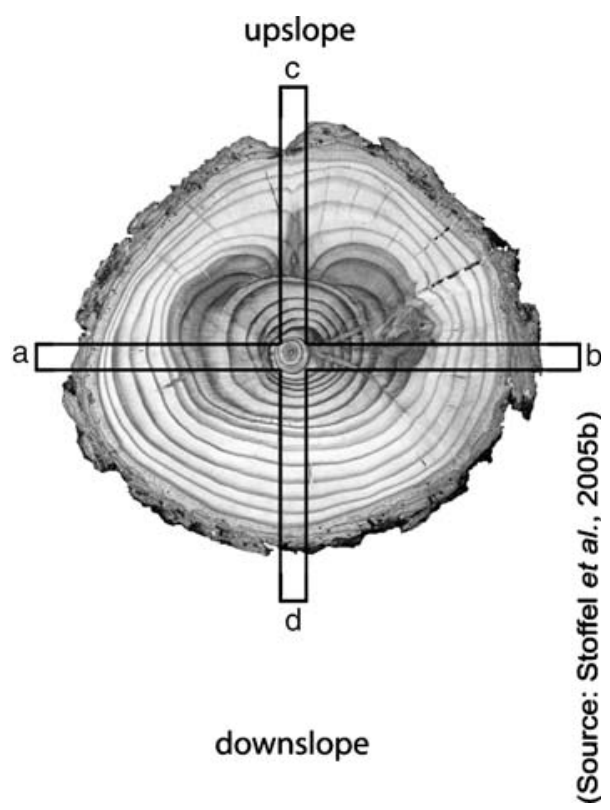

Figure 3. Cross-section of a scarred European larch (Larix decidua) with indication of the sampling positions a, b, c and d for increment cores. Increment cores are extracted at the height of the injury.

perpendicular to the slope (cores a, b) as well as cores extracted from the visible wound and any overgrowing calluses.

Samples are then prepared in the laboratory (Phipps, 1985; Krusic et al., 1987) and analyzed visually, with obvious growth anomalies such as abrupt growth changes, the onset of reaction wood, resin ducts or scars noted on skeleton plots (Schweingruber et al., 1990). This graphic method assists in cross-dating samples by helping in the identification and location of missing or false rings through comparison of one tree-ring sequence with another or reference sequences (Wiles et al., 1996). In a further step, ring-widths are measured using digital measuring tables. Thereafter, data are processed following the procedures described by Bräker (2002).

As growth reactions can be caused by other than geomorphic factors, increment curves of disturbed trees then need to be cross-dated with a reference chronology. This chronology, built with undisturbed samples from a nearby forest stand, reflects growth conditions driven exclusively by environmental factors such as altitude, slope exposure, temperature, precipitation or occasional insect outbreaks (Fritts, 1976; Graybill, 1982; Cook and Kairiukstis, 1990; Schweingruber, 1996). A comparison of the reference chronology with the tree-ring sequences of disturbed trees enables (i) identification of locally predominant growth patterns from disturbances 
induced by geomorphic processes and (ii) accurate dating of disturbances within a year or less.

Results from the different trees sampled within the study area can then be compared and, sample depth permitting, frequencies or volumes for the geomorphic process in question can be derived. In addition, spatial information on the dispersion or reach of single events can be analyzed and represented with interpolations (Stoffel et al., 2005b).

\section{Case studies focusing on tree rings and past rockfall activity}

\subsection{THE BEGINNINGS}

Surprisingly, and despite the potential of dendrogeomorphological methods, rockfall activity has only rarely been studied through the analysis of tree-ring sequences. The work of Moore and Mathews (1978) seems to represent the first (published) attempt to use dendrogeomorphological methods to date the impacts of rocks on trees. This study resulted in the reconstruction of the historical 'Rubble Creek' rockfall avalanche in southwestern British Columbia (Canada). Later, work by Butler et al. (1986) dated two recent 'rockfall avalanches' in Glacier National Park (Montana, USA). Hétu (1990), Lafortune et al. (1997) and Hétu and Gray (2000) analyzed stem discs from the Gaspé Peninsula (Canada) to determine annual sedimentation rates and recent displacements of forest edges on active scree slopes.

Even though the material causing the scars was in all cases of rockfall origin, the process responsible for the damage to the trees was not rockfall. In the studies presented by Moore and Mathews (1978) and Butler et al. (1986), the process was described as a downslope displacement of rock particles in a "rapid flow-like movement", while different debris transfer processes (e.g., frost-coated clast flows, niveo-aeolian sedimentation, debris flows, snow avalanches) were identified responsible for the remobilization of small rockfall clasts $(\varnothing 2,36 \mathrm{~cm})$ on the slopes of the Gaspé Peninsula.

The first dendrogeomorphological analysis purely focusing on rockfall activity was performed on different slopes at Brienzergrat (Bernese Oberland, Switzerland), where Gsteiger (1989) analyzed three beech (Fagus sylvatica) and four Norway spruce trees (Picea abies). The trees were felled for analysis and 25 stem discs prepared. In total, 56 rockfall scars were identified, 37 in the beech and 19 in the spruce samples. Even though the century-old trees were felled for analysis, only the lowermost sections of the trunks were analyzed; scars occurring higher on stems were disregarded. 


\subsection{LATER WORKS}

\subsubsection{Studies using stem discs}

A later study using stem discs to determine past rockfall activity was performed at the foot of a slope near Bourg St. Pierre (Valais, Switzerland), where a "rockfall chronology" (1890-1987) was constructed from 30 crosssections taken from the base of previously felled Norway spruce trees (Schweingruber, 1996). A total of 66 scars were identified and periods with either abundant (1953-1960) or infrequent rockfall activity (1941-1949) were determined. The study also indicated that the construction of a road across the slope prevented rockfall from reaching the lowermost part of the slope after 1970. Schweingruber (1996) finally concluded that "rockfall frequency", here, is most likely to be correlated with the frequency of precipitation.

Systematic felling campaigns (bark-beetle eradication) in a forest located at the base of a high limestone cliff in Diemtigtal (Bernese Oberland, Switzerland) allowed investigation of rockfall activity on 33 cross-sections from Norway spruce trees (Perret et al., 2005). Discs were sawn from the remaining tree stumps at about $30 \mathrm{~cm}$ above ground and used to study past rockfall activity (1880-2000). In total, analyses allowed identification of 75 scars and 175 traumatic rows of resin ducts. Results from decadal rockfall activity neatly show that rockfall frequencies remained at a relatively low level throughout the first half of the 20th century. Starting in the 1960 s, frequencies gradually increased, resulting in a relatively high value during the 1990s (Perret et al., 2005).

In the protection forest of Altdorf (Uri, Switzerland), Stoffel (2005a) felled three century-old trees and, in contrast to the studies mentioned above, for the first time trees were studied from base to top by taking a large number of cross-sections: Analysis of the 88 cross-sections of a 97 year-old Norway spruce tree showed 53 different scars located between 10 and $596 \mathrm{~cm}$ above ground. In addition, 105 stem discs were cut and prepared from a 129-year old fir tree (Abies alba): as can be seen from Figure 4, this tree suffered from rockfall impacts 33 times between 1916 and 1995 and scars were found at heights ranging from 17 to $930 \mathrm{~cm}$ above ground. Finally, a 112-year old beech tree was cut into 114 cross-sections. Analysis of the beech discs allowed identification of 103 different scars representing 25 single event years between 1898 and 1994. Figure 5 illustrates one of the lowermost stem discs of this tree with several overgrown scars and includes a histogram showing all reconstructed event years.

In a heavily disturbed protection forest at Täschgufer (Valais, Switzerland), Stoffel et al. (2005c) felled 18 juvenile European larch trees (Larix decidua). In total, 270 stem discs were prepared, with discs taken from the 


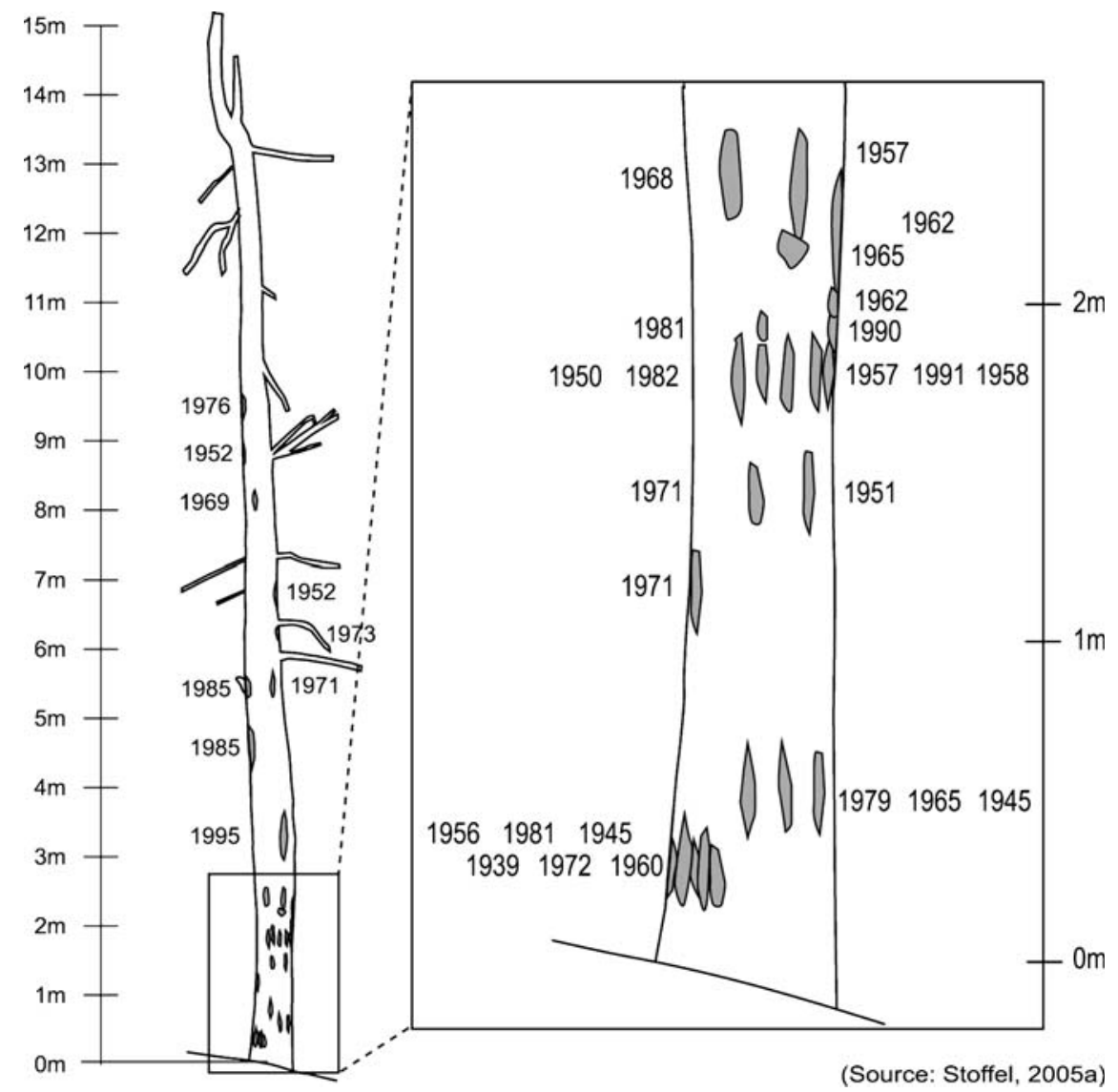

Figure 4. Vertical and horizontal distribution of 33 rockfall injuries reconstructed on an adult fir tree (Abies alba) from the Altdorfer Bannwald (Swiss Alps). While most scars can be found within the first $2 \mathrm{~m}$ above ground, the highest injury was found at a height of $930 \mathrm{~cm}$.

basal area of the trunk up to the crown. Analysis of these discs allowed dating of 180 rockfall impacts for the period 1977-2002. Although rockfall activity caused almost continuous damage to the sampled trees, activity was found to have increased between 1994 and 1996.

All the studies mentioned above furnished valuable evidence of past rockfall activity for the slopes in question. However, they suffer from the limited number of available trees or cross-sections (since trees cannot normally be felled in protection forests and stumps of felled trees are not always readily available). With the exception of possibly Perret et al. (2005), the term 'frequency' should, thus, be read with caution in these studies. 


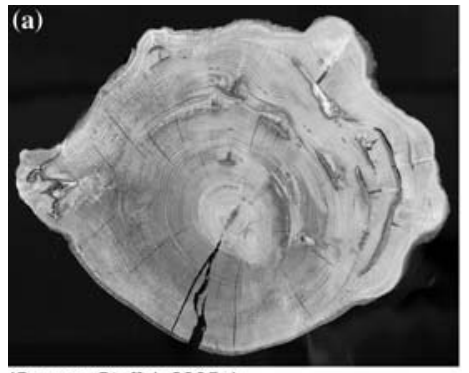

(Source: Stoffel, 2005a)

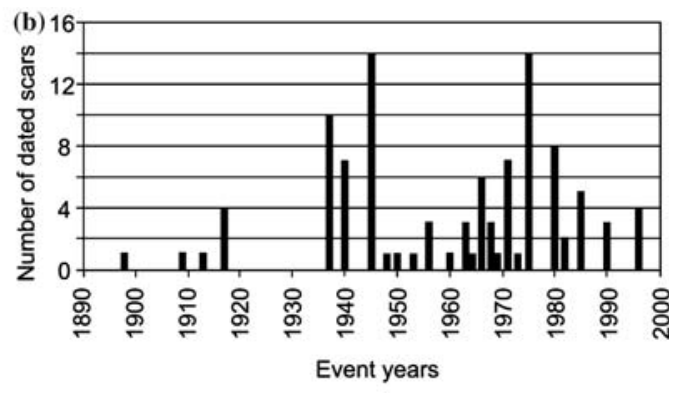

Figure 5. Rockfall activity based on 114 stem discs of a heavily disturbed beech ( $F a$ gus sylvatica) from the Altdorf Bannwald (Swiss Alps): (a) Cross-section taken at the base of the stem showing 13 scars; (b) Histogram with all event years reconstructed on the stem discs of this beech tree.

\subsubsection{Studies using increment cores}

In areas where it is impossible to fell trees, the extraction of increment cores represents a valuable and non-destructive alternative. Moreover, this method normally allows the sampling of a larger number of trees.

Until now, only the protection forest at Täschgufer (Valais, Switzerland) has been extensively studied using increment cores. In this location, a total of 135 severely damaged European larch trees were chosen for analysis (Schneuwly, 2003; Stoffel et al., 2005b). At least four cores were extracted per tree using increment borers (see Figure 3) and further cores were extracted from wounds or overgrown scars, resulting in a depth of 564 samples. In contrast to most studies using stem discs, Stoffel et al. (2005b) studied all types of growth disturbances, illustrated in Figure 2, to date past rockfall activity, mainly focusing on the occurrence of traumatic rows of resin ducts.

In total, 741 growth disturbances were dated between 1600 and 2002. Results indicate that rockfall most commonly occurred in the form of high frequency events of limited volume. However, they also show one large event in 1720, which would have considerably displaced the local forest fringe downslope and eliminated a part of the forest stand in the southern sector of the study area. Rockfall frequencies are represented by means of a rockfall 'rate', which Stoffel et al. (2005b) define as the number of reconstructed rockfall events per meter tree diameter exposed to rockfall (per decade). The results of this analysis are illustrated in Figure 6, showing rockfall periods of high or low frequencies in both the northern and southern sector of the Täschgufer slope. In addition, Figure 6 also illustrates the extent to which the large rockfall of 1720 led to increased activity in the southern sector throughout the 18th century. 


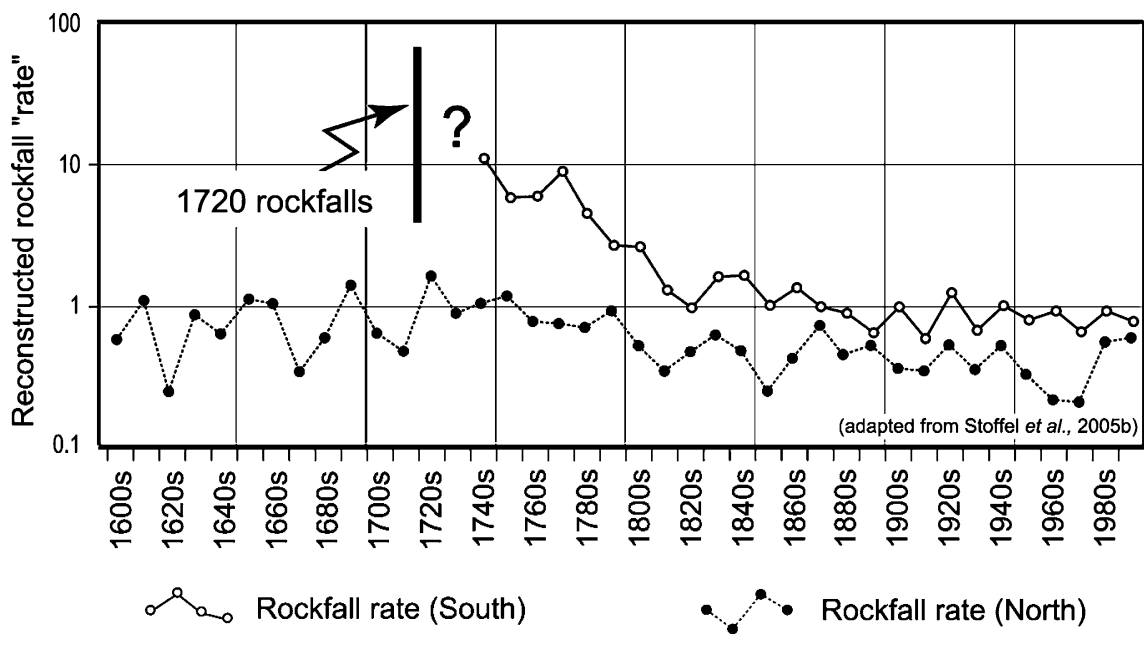

Figure 6. Reconstructed rockfall activity at Täschgufer (Swiss Alps) covering the period 1600-2000: Rockfall activity is represented by the rockfall 'rate' (for explanation see text), indicating that the large 1720 rockfalls temporarily reduced the protection afforded by the forest.

\subsubsection{Combined stem disc and core analyses}

On a slope in the Val Calanca (Grisons, Switzerland), Hopfmüller (1997) sampled 52 stem discs from previously felled and 66 increment cores from 33 living Norway spruce trees. While 42 injuries were found in the crosssections, the increment cores enabled identification of 52 further scars. However, only two thirds of the scars could be precisely dated, as the wood of 22 samples proved to be rotten. The injury age in the decaying samples was less precisely dated with an error margin ranging from \pm 1 to \pm 10 years. Results indicated increased rockfall activity during the 1940s as well as between 1955 and 1965. In addition to small high frequency rockfall events, two large rockfalls (Felsstürze) were identified, causing 12 scars in the winter of $1938 / 39$ and 30 more wounds in the subsequent winter (1939/40).

\subsection{STUDIES ON THE SPATIAL DISTRIBUTION OF ROCKFALL ACTIVITY}

The spatial distribution of rockfall activity can reveal the maximal range, the lateral dispersion and the distribution of recurrence intervals on a slope. Gsteiger (1993) was the first to attempt to illustrate spatial variations in rockfall activity by analyzing the number and distribution of scars visible on stem surfaces to derive rockfall activity maps (Aktivitätskartierung). 
Quantitative analysis of rockfall activity using dendrogeomorphological methods only began to be applied in 1996. Schweingruber (1996) represented the distribution of injured and non-injured trees on a slope near Bourg St. Pierre (Valais Alps, Switzerland) with different dots. In a similar way, Hopfmüller (1997) illustrated the spatial distribution of scars associated with two considerable rockfalls (Felsstürze) in the late 1930s. He also provided an indication of the fall tracks, the range and lateral spread of rockfall boulders. More recently, Stoffel et al. (2005c) used tree rings to differentiate rockfall activity originating from two different source areas at Täschgufer (Valais Alps, Switzerland). In addition, scars induced by natural rockfall activity were clearly separated from rockfall impacts triggered during dam construction works (i.e., excavation works, blasting).

The large amount of rockfall data reconstructed from increment cores at Täschgufer (Stoffel et al., 2005b) made it possible to divide spatial information on past rockfall activity into different time periods. In Figure 7, four 25-year periods were chosen from the last century (1901-2000) to illustrate spatio-temporal variations in rockfall activity on the Täschgufer slope. Again, trees were differentiated into scarred and unaffected trees and results illustrated with either black or white dots.
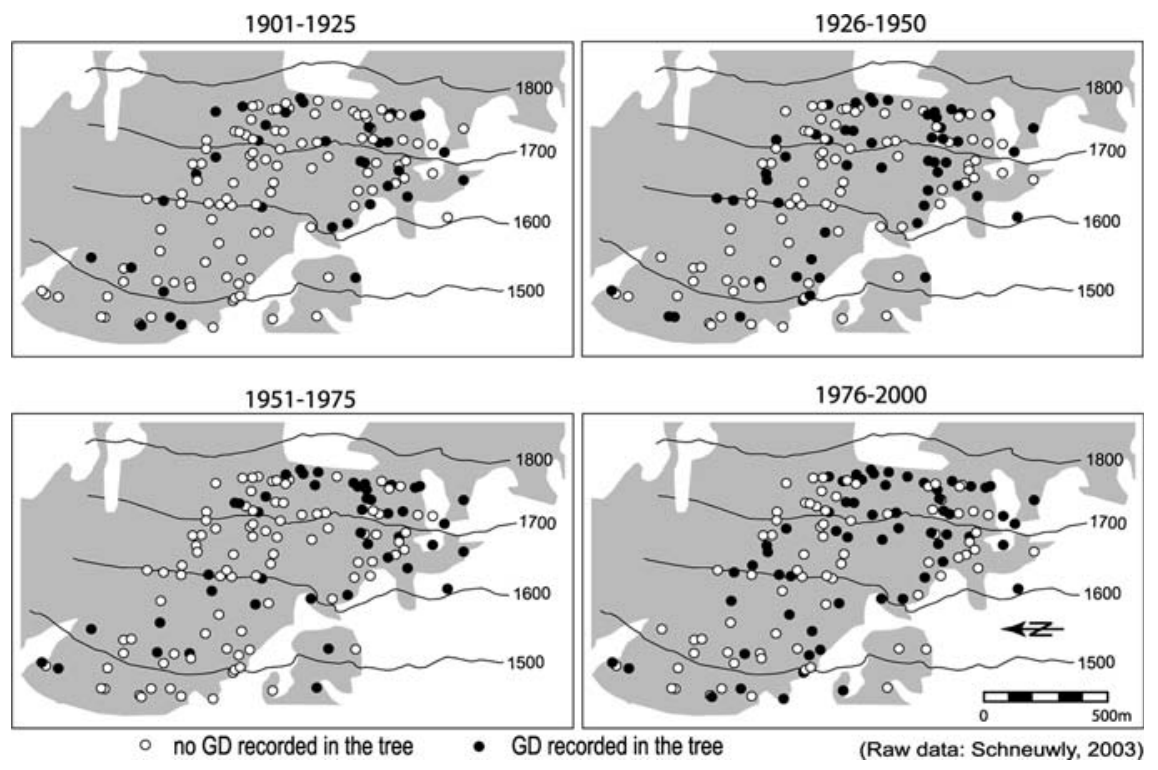

Figure 7. Spatio-temporal variations in rockfall activity derived from different growth disturbances (= GD; e.g., scars, traumatic rows of resin ducts, abrupt growth reductions, reaction wood) at Täschgufer (Swiss Alps). Data are resolved in 25-yr segments for the last century (1901-2000). 
While all of the preceding studies illustrated the presence or absence of rockfall impacts on trees, no information was given on the frequency or the number of reconstructed scars. Very few studies analyzed recurrence intervals of rockfall impacts on trees together with their distribution across slopes in order to illustrate both spatial and temporal variations in rockfall activity. Stoffel et al. (2005b) used interpolations to represent the position of scarred trees and the time elapsed between single events. As can be seen from Figure 8, they found considerable spatial differences in recurrence intervals across the slope, ranging from $<20$ years in some areas to $>150$ years in others. In general, rockfall seems to have caused more damage upslope, while the lower parts of the protection forest suffered less from the disturbances caused through falling, bouncing or rolling rocks and boulders.

\subsection{STUDIES ON THE SEASONAL TIMING OF ROCKFALL ACTIVITY}

The seasonal timing of rockfall activity can be assessed by analyzing the position of scars or traumatic rows of resin ducts within individual tree rings, as illustrated in Figure 9a. Stoffel et al. (2005c) applied this approach while investigating scars and traumatic rows of resin ducts in juvenile European larch trees collected at Täschgufer. Figure 9b shows relative distributions of 'dormancy', earlywood and latewood events at Täschgufer

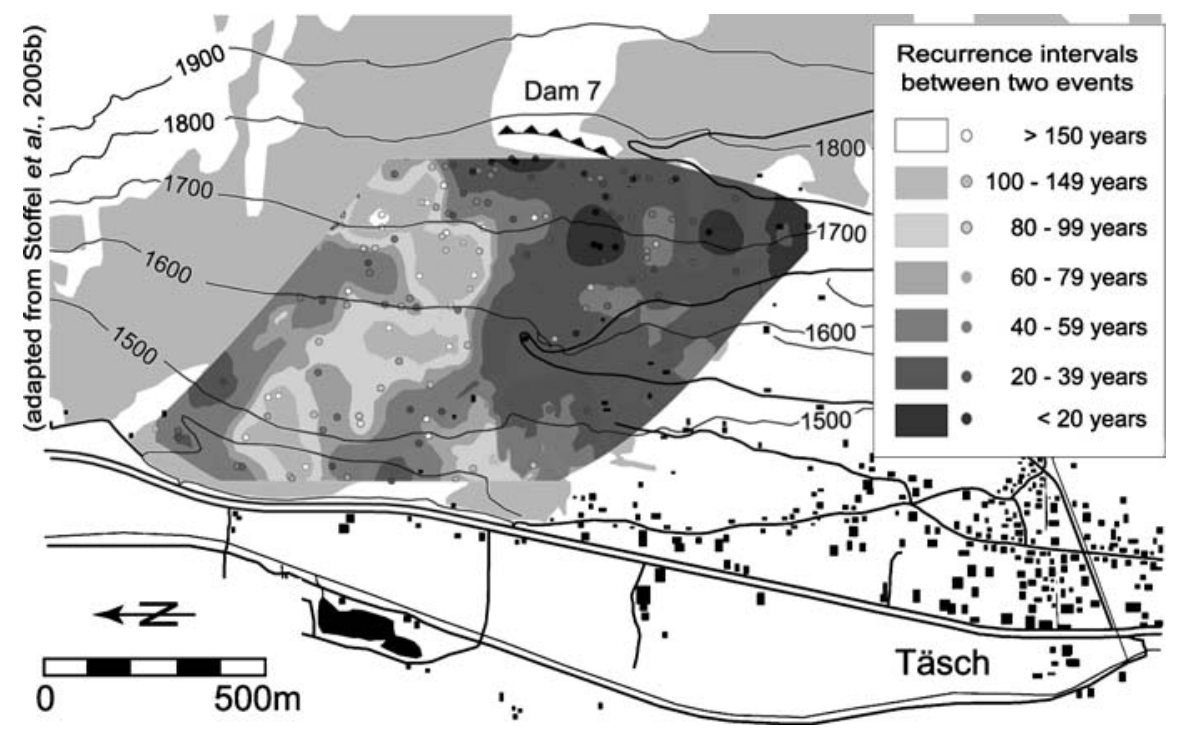

Figure 8. Interpolated recurrence intervals of rockfall at Täschgufer (Swiss Alps) covering the last four centuries. Intervals designate the number of years passing between two reconstructed growth disturbances (GD) on a single tree. 

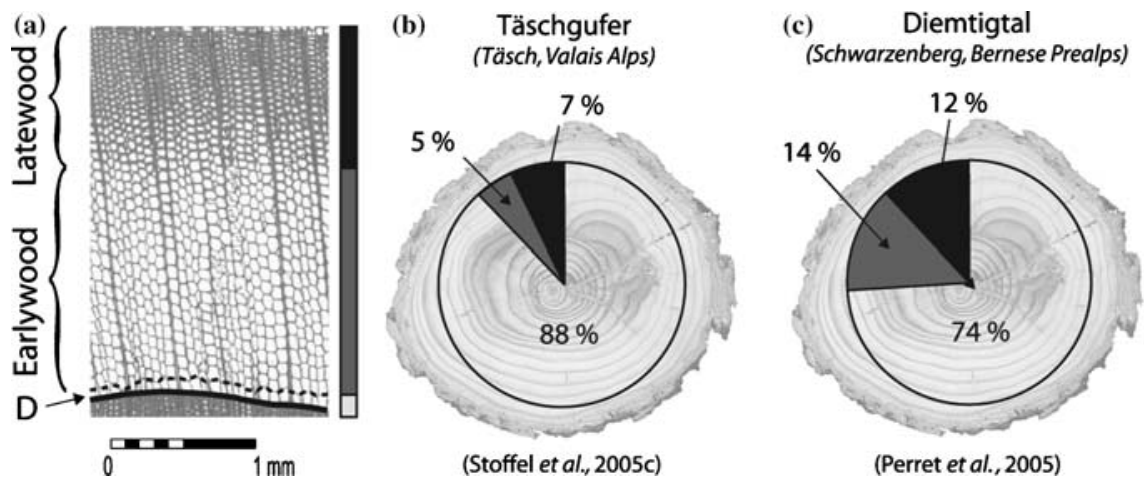

Figure 9. (a) During the period of cell growth, trees first form thin-walled earlywood cells (E) before they start to produce thick-walled latewood (L) cells. At the end of the vegetation period, cell formation ceases and dormancy (D) sets in. The seasonal timing of rockfall activity was assessed on two different slopes in Switzerland, namely on the (b) Täschgufer (Swiss Alps) and the (c) Diemtigtal (Swiss Prealps) slopes. While permafrost exists locally at Täschgufer, seasonal frost occurs during the winter months at Diemtigtal.

between 1977 and 2001, showing that $88 \%$ of the rockfall injuries were caused before the 'vegetation period' (i.e., during 'dormancy'). Direct observations on the slope confirmed these findings, indicating that rockfall was most abundant in April and May, when the active layer of locally existing permafrost starts to thaw along with the ice formed in bedrock joints. In contrast, injuries occurring during the 'vegetation period' were scarce and less frequent during the period of earlywood $(5 \%)$ than latewood formation $(7 \%)$.

Following the procedures described above, Perret et al. (2005) analyzed the seasonal timing of events in growth rings of Norway spruce trees on a rockfall slope in the Swiss Prealps (Diemtigtal, Bernese Oberland). Here, seasonal frost prevails and there is no permafrost. As can be seen from Figure 9c, scars and resin ducts most commonly occurred before the onset of the 'vegetation period' (74\%) between 1950 and 2002. However, scars caused during 'dormancy' are less predominant at Diemtigtal than at Täschgufer and rockfall events during the 'vegetation period' are more frequent; with $15 \%$ of all scars found in earlywood and $11 \%$ in latewood cell layers.

\section{Discussion and conclusions}

\subsection{STRENGTHS AND WEAKNESSES}

One of the primary strengths of dendrogeomorphology is that it can be used to supply data on rockfall activity on forested slopes where 
historical records are either incomplete or lacking. In such situations it can provide researchers with data on the frequencies, volumes, spatial distributions and seasonality of past rockfalls. Results from dendrogeomorphological rockfall research may be used to improve the quality of data in studies dealing with hazard or risk assessment in a number of ways:

- The seasonal timing of rockfall activity can be estimated to help in the better management of risks on hiking trails allowing them to be closed during periods of enhanced rockfall activity.

- Seasonal differentiation of events may also be integrated with analysis focusing on other features such as transportation corridors or inhabited areas.

- Engineers can be provided with information on where and how often rockfalls recurred in the past and, thus, improve the quality of the data upon which countermeasures such as rockfall dams, barriers or restraining nets are based.

- The influence of rockfall protection dams on the range and distribution of rockfall events can be determined (Stoffel et al., 2005b).

- Tree-ring data can be used for controlling results from rockfall modeling, as recently demonstrated on different slopes in Switzerland by Stoffel et al. (2005d).

- Forest managers can use dendrogeomorphological studies to define their future priorities (e.g., Kienholz and Mani, 1994; Berger and Rey, 2004). As Motta and Haudemand (2000) pertinently argue, appropriate management and accurate evaluation of the ecosystem integrity of protection forests not only relies on information dealing with past silvicultural treatments, but also has to consider past evidence of disturbances such as rockfall.

Although this review clearly shows that dendrogeomorphology has an enormous potential for showing yearly fluctuations, decadal ratios or spatial distribution in rockfall activity over several centuries, there are a number of weaknesses. Techniques and methods need further refinement, and sampling strategies such as the determination of sampling heights or the choice of trees have to be carefully established, as they strongly influence the quality and quantity of results (Stoffel, 2005b; Stoffel and Perret, 2005). Similarly, because trees may overgrow wounds and, thus, blur evidence of past events on the stem surface, cross-sections and increment cores should be selected randomly within the forest stand. Otherwise, there is a danger of overestimating recent and underestimating older rockfall events. 


\subsection{FUTURE DIRECTIONS}

In the future, tree-ring analysis will need to incorporate further promising research directions, such as the analysis of rockfalls triggered during seismic activity. The role of earthquakes on rockfall activity has so far only been investigated through lichenometric (Bull and Brandon, 1998) or radiocarbon methods (Becker and Davenport, 2003), but not with dendrogeomorphology. There is thus a great need to incorporate this promising aspect into tree ring and rockfall research as well. While snow avalanches, debris flows or flooding have been analyzed extensively using tree-ring sequences, studies of past rockfall activity are comparatively scarce. The great potential of dendrogeomorphology for rockfall research has been largely ignored. Thus, we should need Solomina's (2002) plea for comparative studies conducted in different regions aimed at identifying or possibly even quantifying the influence of past and current climate variations on rockfall activity.

\section{Acknowledgements}

Michel Monbaron is acknowledged for both financially and morally supporting this research. While Simone Perret and Michelle Bollschweiler made helpful comments on an earlier version of the paper, Heather Murray improved the English. Finally, I gratefully acknowledge the suggestions made by Vanessa Winchester and an anonymous reviewer.

\section{References}

Alestalo, J.: 1971, Dendrochronological interpretation of geomorphic processes, Fennia 105, $1-139$.

André, M. F.: 1997, Holocene rockwall retreat in Svalbard: A triple-rate evolution, Earth Surf. Process. Landf. 22, 423-440.

Baillie, M. G. L.: 1994, Dendrochronology raises questions about the nature of the AD 536 dust-veil event, Holocene 4, 212-217.

Baillifard, F., Jaboyedoff, M., and Sartori, M.: 2003, Rockfall hazard mapping along a mountainous road in Switzerland using a GIS-based parameter rating approach, Nat. Hazards Earth Syst. Sci. 3, 431-438.

Barnikel, F.: 2004, The value of historical documents for hazard zone mapping, Nat. Hazards Earth Syst. Sci. 4, 599-613.

Baumann, F. and Kaiser, K. F.: 1999, The Multetta debris fan, eastern Swiss Alps: a 500-year debris flow chronology, Arct. Antarct. Alp. Res. 31(2), 128-134.

Becker, A. and Davenport, C. A.: 2003, Rockfalls triggered by the AD 1356 Basle Earthquake, Terra Nova 15, 258-264.

Berger, F. and Rey, F.: 2004, Mountain protection forests against natural hazards and risks: New French developments by integrating forests in risk zoning, Nat. Hazards 33, 395-404.

Biondi, F., Estrada, I. G., Ruiz, J. C. G., and Torres, A. E.: 2003, Tree growth response to the 1913 eruption of Volcán de Fuego de Colima, Mexico, Quat. Res. 59, 293-299. 
Bräker, O. U.: 2002, Measuring and data processing in tree-ring research - a methodological introduction, Dendrochronologia 20(1-2), 203-216.

Bräuning, A.: 1995, Zur Anwendung der Dendrochronologie in den Geowissenschaften, Die Erde 126, 189-204.

Brown, P. M. and Swetnam, T. W.: 1994, A cross-dated fire history from coast redwood near Redwood National Park, California, Can. J. For. Res. 24, 21-31.

Budetta, P.: 2004, Assessment of rockfall risk along roads, Nat. Hazards Earth Syst. Sci. 4, 7181.

Bull, W. B. and Brandon, M. T.: 1998, Lichen dating of earthquake-generated regional rockfall events, Southern Alps, New Zealand, Bull. Geol. Soc. Am. 110, 60-84.

Bull, W. B., King, J., Kong, F., Moutoux, F., and Phillips, W. M.: 1994, Lichen dating of coseismic landslide hazards in alpine mountains, Geomorphology 10, 253-264.

Bunce, C. M., Cruden, D. M., and Morgenstern, N. R.: 1997, Assessment of the hazard of rock fall on a highway, Can. Geotech. J. 34, 344-356.

Butler, D. R., Oelfke, J. G., and Oelfke, L. A.: 1986, Historic rockfall avalanches, northeastern Glacier National Park, Montana, USA, Mountain Res. Dev. 6, 261-271.

Camarero, J. J., Guerrero-Campo, J., and Gutiérrez, E.: 1998, Tree-ring growth and structure of Pinus uncinata and Pinus sylvestris in the Central Spanish Pyrenees, Arct. Alp. Res. 30(1), 1-10.

Cook, E. R. and Kairiukstis, L. A.: 1990, Methods of dendrochronology-Applications in the environmental sciences, Kluwer, London.

DeGraff, J. V. and Agard, S. S.: 1984, Defining geologic hazards for natural resources management using tree-ring analysis, Env. Geol. Water Sci. 6(3), 147-155.

Douglas, G. R.: 1980, Magnitude frequency study of rockfall in Co. Antrim, North Ireland, Earth Surf. Process. Landf. 5, 123-129.

Dussauge, C., Grasso, J. R., and Helmstetter, A.: 2003, Statistical analysis of rockfall volume distribution: Implications for rockfall dynamics, J. Geophys. Res. 108(B6), 2286.

Dussauge-Peisser, C., Helmstetter, A., Grasso, J. R., Hantz, D., Desvarreux, P., Jeannin, M., and Giraud, A.: 2002, Probabilistic approach to rock fall hazard assessment: potential of historical data analysis, Nat. Hazards Earth Syst. Sci. 2, 15-26.

Evans, S. G. and Hungr, O.: 1993, The assessment of rockfall hazards at the base of talus slopes, Can. Geotech. J. 30, 620-636.

Fantucci, R. and Sorriso-Valvo, M.: 1999, Dendrogeomorphological analysis of a slope near Lago, Calabria (Italy), Geomorphology 30, 165-174.

Fritts, H. C.: 1976, Tree Rings and Climate, Academic Press, London.

Gardner, J. S.: 1983, Rockfall Frequency and Distribution, Z. Geomorph. N.F. 27(3), 311-324.

Gsteiger, P.: 1993, Steinschlagschutzwald. Ein Beitrag zur Abgrenzung, Beurteilung und Bewirtschaftung, Schweiz. Z. Forstwes. 144(2), 115-132.

Gsteiger, P.: 1989, Steinschlag, Wald, Relief. Empirische Grundlagen zur Steinschlagmodellierung, Geographisches Institut, Universität Bern.

Graybill, D. A.: 1982, Chronology development and analysis, In: M. K. Hughes (ed), Climate from Tree Rings, Cambridge: Cambridge University Press, pp. 21-28.

Guzzetti, F.: 2000, Landslide fatalities and the evaluation of landslide risks in Italy, Eng. Geol. 58, 89-107.

Guzzetti, F. and Tonelli, G.: 2004, Information system on hydrological and geomorphological catastrophes in Italy (SICI): A tool for managing landslide and flood hazards, Nat. Hazards Earth Syst. Sci. 4, 213-232.

Guzzetti, F., Reichenbach, P., and Ghigi, S.: 2004, Rockfall hazard and risk assessment along a transportation corridor in the Nera Valley, Central Italy, Env. Manage. 34(2), 191-208. 
Guzzetti, F., Carrara, A., Cardinali, M., and Reichenbach, P.: 1999, Landslide hazard evaluation: a review of current techniques and their application in a multi-scale study, Central Italy, Geomorphology 31, 181-216.

Hantz, D., Vebgeon, J. M., and Dussauge-Peisser, C.: 2003, An historical, geomechanical and probabilistic approach to rock-fall hazard assessment, Nat. Hazards Earth Syst. Sci. 3, 693-701.

Hebertson, E. G. and Jenkins, M. J.: 2003, Historic climate factors associated with major avalanche years on the Wasatch Plateau, Utah, Cold Reg. Sci. Technol. 37, 315-332.

Hétu, B.: 1990, Evolution récente d'un talus d'éboulis en milieu forestier, Gaspésie, Québec, Geogr. phys. Quat. 44, 199-215.

Hétu, B. and Gray, J. T.: 2000, Effects of environmental change on scree slope development throughout the postglacial period in the Chic-Choc Mountains in the northern Gaspé Peninsula, Québec, Geomorphology 32, 335-355.

Hopfmüller, M. W.: 1997, Datierung und räumliche Erfassung von Steinschlag- und Felssturzereignissen mit dendrochronologischen Methoden, Institut für Geographie, Universität Regensburg, Regensburg.

Hungr, O. and Beckie, R. D.: 1998, Assessment of the hazard from rock fall on a highway, Can. Geotech. J. 35, 409.

Hungr, O., Evans, S. G., and Hazzard, J.: 1999, Magnitude and frequency of rock falls along the main transportation corridors of south-western British Colombia, Can. Geotech. J. 36, 224-238.

Hupp, C. R.: 1988, Plant ecological aspects of flood geomorphology and paleoflood history, In: V. R. Baker, C. R. Kochel \& P. C. Patton (eds), Flood Geomorphology, New York: Wiley and Sons, pp. 335-356.

Jacoby, G. C.: 1997, Application of tree ring analysis to paleoseismology, Rev. Geophys. 35(2), $109-124$.

Jacoby, G. C., Sheppard, P. R., and Sieh, K. E.: 1988, Irregular recurrence of large earthquakes along the San Andreas Fault. Evidence from trees., Science 241, 196-199.

Kaiser, K. F. and Kaiser-Bernhard, C.: 1987, The Katmai eruption of 1912 and the Alaska earthquake of 1964 as reflected in the annual rings of Sitka Spruce on Kodiak Island, Dendrochronologia 5, 111-125.

Kienholz, H. and Mani, P.: 1994, Assessment of geomorphic hazards and priorities for forest management on the Rigi north face, Switzerland, Mountain Res. Dev. 14(4), 321328.

Kienholz, H., Mani, P., and Kläy, M.: 1988, Rigi Nordlehne. Beurteilung der Naturgefahren und waldbauliche Prioritätenfestlegung. In: Proc. Internationales Symposium Interpraevent 1988, Graz, Austria, Band 1: 161-174.

Krusic, P. M., Kenney, M., and Hornbeck, J.: 1987, Preparing increment cores for ring-width measurements, Northern J. Appl. Forest. 4, 104-105.

Lafortune, M., Filion, L., and Hétu, B.: 1997, Dynamique d'un front forestier sur un talus d'éboulis actif en climat tempéré froid (Gaspésie, Québec), Geogr. phys. Quat. 51(1), 115.

Lateltin, O., Beer, C., Raetzo, H., and Caron, C.: 1997, Landslides in Flysch terranes of Switzerland: Causal factors and climate change, Eclogae Geol. Helv. 90(3), 401-406.

LePage, H. and Bégin, Y.: 1996, Tree-ring dating of extreme water level events at Lake Bienville, Subarctic Québec, Canada. Arct. Alp. Res. 28(1), 77-84.

Lin, A. and Lin, S.: 1998, Tree damage and surface displacement: the 1931 M 8.0 Fuyun Earthquake, J. Geol. 106, 751-757.

Luckman, B. H.: 1976, Rockfalls and rockfall inventory data: Some observations from Surprise Valley, Jasper National Park, Earth Surf. Process. Landf. 1, 287-298. 
Luckman, B. H. and Fiske, C. J.: 1995, Estimating long-term rockfall accretion rates by lichenometry, In: O. Slaymaker (eds), Steepland Geomorphology, Chichester: Wiley, pp. 233-255.

Malamud, B. D., Turcotte, D. M., Guzzetti, F., and Reichenbach, P.: 2004, Landslide inventories and their statistical Properties, Earth Surf. Process. Landf. 29, 687-711.

McCarroll, D., Shakesby, R. A., and Matthews, J. S.: 2001, Enhanced Rockfall Activity during the Little Ice Age: Further lichenometric evidence from a Norwegian talus, Permafrost Periglac. Process. 12, 157-164.

McCarroll, D., Shakesby, R. A., and Matthews, J. S.: 1998, Spatial and temporal patterns of Late Holocene rockfall activity on a Norwegian talus slope: lichenometry and simulationmodelling approach, Arct. Alp. Res. 30, 51-60.

Moore, D. P. and Mathews, W. H.: 1978, The Rubble Creek landslide, southwestern British Columbia, Can. J. Earth Sci. 15, 1039-1052.

Motta, R. and Haudemand, J. C.: 2000, Protective forests and silvicultural stability - an example of planning in the Aosta Valley, Mountain Res. Dev. 20(2), 180-187.

Ortloff, W., Goldammer, J. G., Schweingruber, F. H., and Swetnam, T. W.: 1995, Jahrringanalytische Untersuchungen zur Feuergeschichte eines Bestandes von Pinus ponderosa Dougl. ex Laws. in den Santa Rita Mountains, Arizona, USA, Forstarchiv 66, 206-214.

Patten, R. S. and Knight, D. H.: 1994, Snow avalanches and vegetation pattern in cascade canyon, Grand Teton National Park, Wyoming, USA, Arct. Alp. Res. 26(1), 35-41.

Perret, S., Stoffel, M., and Kienholz, H.: 2005, Spatial and temporal rockfall activity in a forest stand in the Swiss Prealps - a dendrogeomorphological case study. Geomorphology, in press.

Phipps, R.L.: 1985, Collecting, preparing, crossdating, and measuring tree increment cores. U.S. Geol. Surv. Wat. Res. Inv. Rep. 85-4148, pp. 1-48.

Rayback, S. A.: 1998, A dendrogeomorphological analysis of snow avalanches in the Colorado Front Range, USA, Phys. Geogr. 19(6), 502-515.

Rigling, A., Bräker, O., Schneiter, G., and Schweingruber, F.: 2002, Intra-annual tree-ring parameters indicating differences in drought stress of Pinus sylvestris forests within the Erico-Pinion in the Valais (Switzerland), Plant Ecol. 163, 105-121.

Schneuwly, D.: 2003, 500-jährige Rekonstruktion der Steinschlagfrequenz im Täschgufer anhand dendrogeomorphologischer Methoden, University of Fribourg, Fribourg.

Schweingruber, F. H., Eckstein, D., Serre-Bachet, F., and Bräker, O. U.: 1990, Identification, presentation and interpretation of event years and pointer years in dendrochronology, Dendrochronologia 8, 9-39.

Schweingruber, F. H.: 1996, Tree Rings and Environment. Dendroecology., Verlag Paul Haupt, Bern, Stuttgart.

Shroder, J. F.: 1980, Dendrogeomorphology: Review and new techniques of tree-ring dating, Prog. Phys. Geogr. 4, 161-188.

Shroder, J. F.: 1978, Dendrogeomorphological analysis of mass movement on Table Cliffs Plateau, Utah, Quat. Res. 9, 168-185.

Shroder, J. F. and Butler, D. R.: 1987, Tree-ring analysis in the earth sciences. In: Proc. Int. Symposium on Ecological Aspects of Tree-Ring Analysis, Tarrytown NY, pp. 186-212.

Solomina, O.: 2002, Dendrogeomorphology: Research requirements, Dendrochronologia 20(12), 233-245.

Stefanini, M. C.: 2004, -temporal analysis of a complex landslide in the Northern Apennines (Italy) by means of dendrochronology, Geomorphology 63, 191-202.

St. George, S. and Nielsen, E.: 2003, Palaeoflood records for the Red River, Manitoba, Canada, derived from anatomical tree-ring signatures, Holocene 13(4), 547-555.

Stoffel, M.: 2005a, Assessing the vertical distribution and visibility of rockfall scars in trees, Schweiz. Z. Forstwes. 156(6), 195-199. 
Stoffel, M.: 2005b, Spatio-temporal analysis of rockfall activity into forests - results from treering analysis and modeling approaches. Department of Geosciences, Geography, University of Fribourg, GeoFocus 12, 1-188.

Stoffel, M. and Perret, S.: 2005, Reconstructing past rockfall activity with tree rings: some methodological considerations. Dendrochronologia, in review.

Stoffel, M., Lièvre, I., Conus, D., Grichting, M. A., Raetzo, H., Gärtner, H. W., and Monbaron, M.: 2005a, 400 years of debris flow activity and triggering weather conditions: Ritigraben VS, Switzerland, Arct. Antarct. Alp. Res. 37(3), 387-395.

Stoffel, M., Schneuwly, D., Bollschweiler, M., Lièvre, I., Delaloye, R., Myint, M., and Monbaron, M.: 2005b, Analyzing rockfall activity (1600-2002) in a protection forest - a case study using dendrogeomorphology, Geomorphology 68(3-4), 224-241.

Stoffel, M., Lièvre, I., Monbaron, M., and Perret, S.: 2005c, Seasonal timing of rockfall activity on a forested slope at Täschgufer (Valais, Swiss Alps) - a dendrochronological approach, Z. Geomorph. 49(1), 89-106.

Stoffel, M., Wehrli, A., Kühne R., Dorren, L. K. A., Perret, S. and Kienholz, H.: 2005d, Predicting rockfall patterns in mountain forests using a 3D model. For. Ecol. Manage., (in press).

Strunk, H.: 1997, Dating of geomorphological processes using dendrogeomorphological methods, Catena 31, 137-151.

Strunk, H.: 1995, Dendrochronologische Methoden zur Ermittlung der Murfrequenz und Beispiele ihrer Anwendung, Roderer Verlag, Regensburg.

Wiles, G. C., Calkin, P. E., and Jacoby, G. C.: 1996, Tree-ring analysis and Quaternary geology: Principles and recent applications, Geomorphology 16, 259-272. 